See discussions, stats, and author profiles for this publication at: https://www.researchgate.net/publication/234059154

\title{
Evolutionary and systematic relationships among tuco-tucos of the Ctenomys pundti complex (Rodentia: Octodontidae): A cytogenetic and morphological approach
}

Article in Mammalia · March 2005

DOI: 10.1515/mamm.2005.006

4 authors, including:

Sergio I. Tiranti

National University of Comahue

10 PUBLICATIONS 159 CITATIONS

SEE PROFILE

Fernando Dyzenchauz

National Scientific and Technical Research Council

5 PUBLICATIONS 86 CITATIONS

SEE PROFILE

Esteban Hasson

University of Buenos Aires

341 PUBLICATIONS 2,323 CITATIONS

SEE PROFILE

Some of the authors of this publication are also working on these related projects:

Genome Assembly of two Drosophila species and comparative phylogenomic analysis of the Drosophila buzzatii cluster View project

Phylogeography of the subterranean rodent, Ctenomys talarum, in Argentine (Rodentia: Octodontidae). View project 


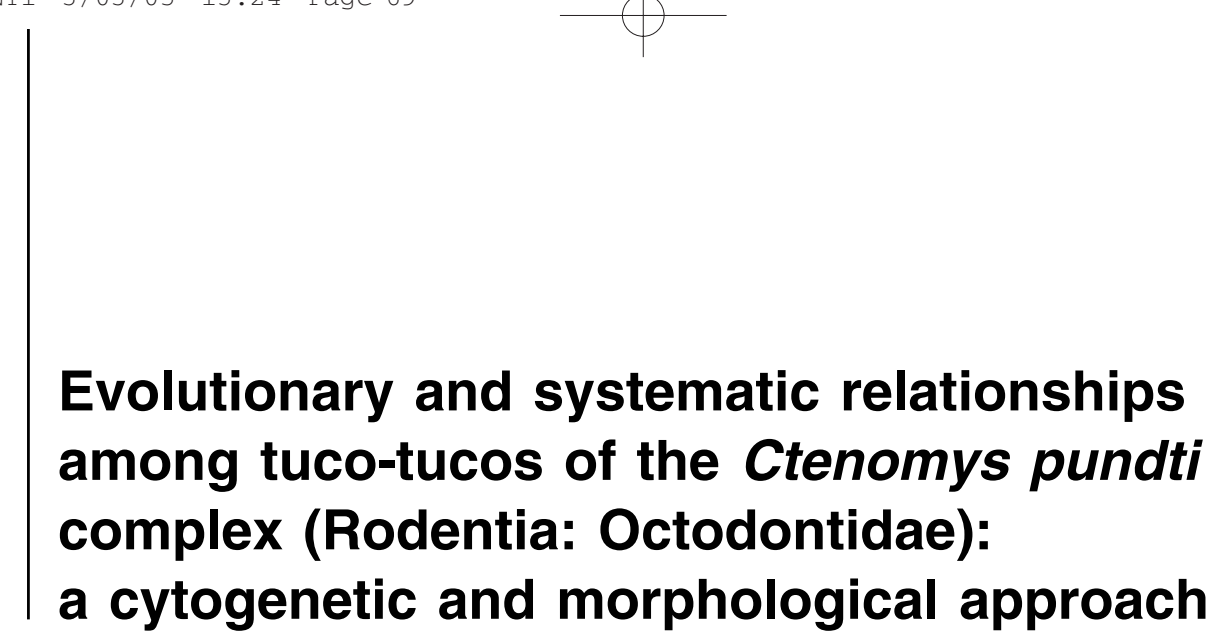

Sergio I. TIRANTI

Facultad de Ciencias Exactas y Naturales, Universidad Nacional de La Pampa, Uruguay 151, 6300. Santa Rosa, La Pampa (Argentina)

Fernando J. DYZENCHAUZ Universidad CAECE, Dpto. de Ciencias Biológicas, Tte. Gral. Juan D. Perón 2933, 1198 Buenos Aires (Argentina)

Esteban R. HASSON GIBE (Grupo de Investigación en Biología Evolutiva), Dpto. de Ciencias Biológicas, FCEyN, Universidad de

Alicia I. MASSARINI Buenos Aires, Pabellón II, $4^{\circ}$ piso, Cdad. Universitaria, Nuñez, 1428 Buenos Aires (Argentina) alicia@biolo.fcen.uba.ar

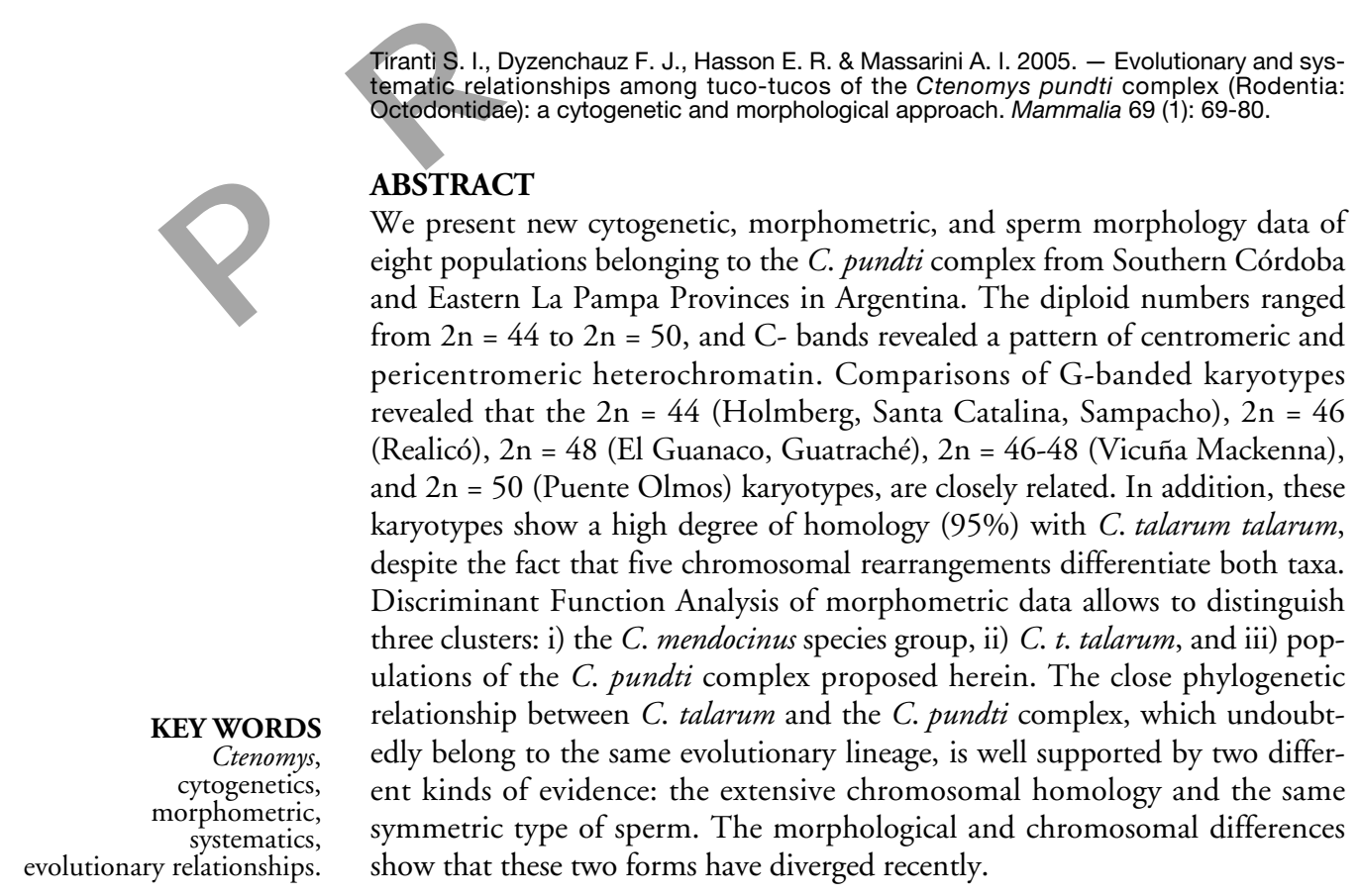




\section{INTRODUCTION}

The fossorial rodents of the genus Ctenomys, commonly known as tuco-tucos, are characterized by an extensive karyotypic heterogeneity, ranging from $2 \mathrm{n}=10$ in C. steinbachi to $2 \mathrm{n}=70$ in C. pearsoni and C. dorbignyi (Reig \& Kibliski 1969; Anderson et al. 1987; Cook et al. 1990; Ortells et al. 1990; Reig et al., 1990; Gallardo 1991; Ortells 1995). However, some species from western and central Argentina, referred to as the C. mendocinus group (Massarini et al. 1991; Freitas 1994; D’Elía et al. 1999), show a similar karyotype of $2 n=47$ to 48 , and recently has been described de $2 n=46$ karyomorph for two population of C. azarae (Massarini et al. 1998). Moreover, some species exhibit a wide array of chromosomal polymorphisms, and interpopulation variation (Massarini et al. 1991; Freitas 1995; Massarini et al. 1998). The significance of this extensive intra and interspecific chromosomal variation has been the subject of considerable debate (Baker et al. 1983; Reig 1989; Nevo 1991; Ortells \& Barrantes 1994; Freitas 1994; Freitas 1997).

In one of the best studied species, Ctenomys talarum, two subspecies are currently recognized, C. t. recessus and C. t. talarum which include several populations distributed along the Atlantic coast of Buenos Aires Province, varying in diploid number from $2 n=46$ to $2 n=50$, as well as other populations in central and western areas of the species' distribution range, whose karyotypes have not been yet studied (Contreras \& Reig 1965; Vidal Rioja 1985).

Moreover, C. talarum recessus is, in certain areas, sympatric with $C$. australis, which belongs to the C. mendocinus group.

Sperm morphology has also been used to discriminate between species groups in the genus. 
TABLE 1. - Collection localities of Ctenomys used for morphometric analysis.

\begin{tabular}{|c|c|c|c|c|}
\hline Species & Locality & Coordinates & males & females \\
\hline \multirow[t]{3}{*}{ C. australis } & Claromecó & $38^{\circ} 52^{\prime} \mathrm{S} 60^{\circ} 02^{\prime} \mathrm{W}$ & 5 & \\
\hline & Monte Hermoso & $38^{\circ} 42^{\prime} \mathrm{S} 60^{\circ} 45^{\prime} \mathrm{W}$ & 8 & \\
\hline & Necochea & $38^{\circ} 32^{\prime}$ S $58^{\circ} 46^{\prime} \mathrm{W}$ & 16 & 23 \\
\hline \multirow[t]{2}{*}{ C. azarae } & Anguil & $36^{\circ} 32^{\prime} \mathrm{S} 64^{\circ} 01^{\prime} \mathrm{W}$ & 4 & \\
\hline & Santa Rosa & $36^{\circ} 37^{\prime} \mathrm{S} 64^{\circ} 17^{\prime} \mathrm{W}$ & 1 & 4 \\
\hline C. mendocinus & C. San Isidro & $32^{\circ} 53^{\prime} \mathrm{S} 68^{\circ} 49^{\prime} \mathrm{W}$ & 12 & 16 \\
\hline C. porteousi & Bonifacio & $36^{\circ} 49^{\prime}$ S $62^{\circ} 13^{\prime}$ W & 18 & 20 \\
\hline \multirow[t]{5}{*}{ C. pundti } & Puente Olmos & $33^{\circ} 25^{\prime} \mathrm{S} 63^{\circ} 06^{\prime} \mathrm{W}$ & 6 & \\
\hline & Realicó & $34^{\circ} 59^{\prime} \mathrm{S} 64^{\circ} 16^{\prime} \mathrm{W}$ & 3 & 1 \\
\hline & Santa Catalina & $33^{\circ} 04^{\prime}$ S $64^{\circ} 32^{\prime} \mathrm{W}$ & 10 & 3 \\
\hline & Vicuña Mackenna & $33^{\circ} 54^{\prime} \mathrm{S} 64^{\circ} 23^{\prime} \mathrm{W}$ & 7 & \\
\hline & El Guanaco & $36^{\circ} 19^{\prime} \mathrm{S} 66^{\circ} 17^{\prime} \mathrm{W}$ & & 6 \\
\hline \multirow[t]{2}{*}{ C.t. talarum } & Magdalena & $34^{\circ} 52^{\prime}$ S $57^{\circ} 53^{\prime} \mathrm{W}$ & 22 & 22 \\
\hline & Santa Clara & $37^{\circ} 58^{\prime}$ S $57^{\circ} 34^{\prime} \mathrm{W}$ & 21 & 23 \\
\hline
\end{tabular}

Number of males and females used in morphometric analysis, localities of collection with its coordinates, and species to which they belong.

Three types of sperm have been described: symmetric, simple-asymmetric and complexasymmetric (Vitullo et al. 1988; Vitullo \& Cook 1991; Freitas 1995). C. talarum has symmetric sperm whereas species of the $C$. mendocinus group have simple asymmetric sperm.

In Northern Córdoba province, new species with assymetric sperm have recently been described (Giménez et al. 1999), but in Southern Córdoba and Eastern La Pampa provinces, there is a suite of Ctenomys populations with symmetric sperm that has not been cytogenetically characterized yet. Although, C. azarae was described from material collected in La Pampa Province (Thomas 1903), in southern Córdoba the only described taxa is Ctenomys pundti (Nehring, 1900, type locality: Alejo Ledesma, Marcos Juárez Department). These two species can be easily distinguished in the field by external morphology. Ctenomys azarae is larger and more robust, having a bigger hindfoot, than Ctenomys pundti, which is more similar to $C$. talarum recessus. The skull of $C$. azarae is larger with wide auditory bullae, while C. pundti and C. talarum have narrower bullae.

Here we report new cytogenetic, morphometric, and sperm type data of Ctenomys populations from Southern Córdoba and Eastern La Pampa, which may help to interpret the phylogenetic relationships among these populations and other taxa of the genus of central Argentina.

\section{MATERIAL AND METHODS}

A morphometric comparative study based on 24 craniometric variables of 241 adult specimens from a total of 14 localities, 10 in male samples and 12 in female samples, was performed on data from Ortells (1990) and Massarini (1992) (Table 1). The studied craniometric variables are shown in Fig. 1. The data were analyzed by means of Discriminant Function Analysis (DFA), using the program STATISTICA. This kind of analysis allows to find a linear combination of variables that maximize the differences among previously defined groups. Groups were defined according to the geogrphapic sampling locality, which corresponds to local populations.

Chromosomal preparations of C. pundti and C. t. talarum specimens were obtained from bone marrow of animals injected with yeast one day before sacrifice (Lee \& Elder 1980), and G- and C- banded karyotypes by the methods of Seabright (1971) and Hsu (1974), respectively. Chromosomal nomenclature follows Levan et al. (1964), and nomenclature relating to the chromosomal size and arrangement of chromosome 

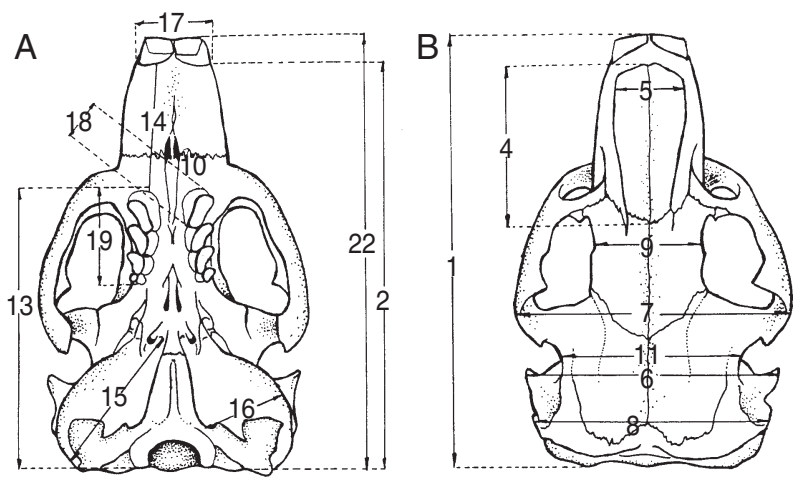

C
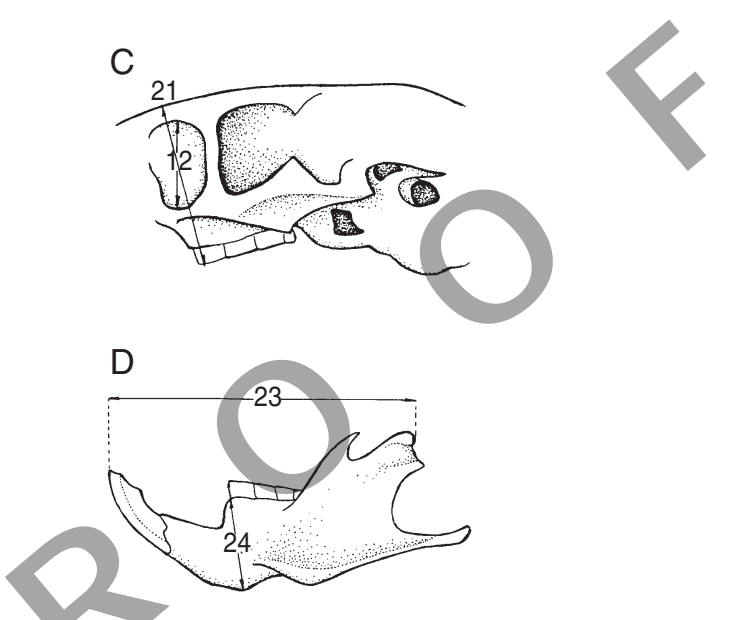

FIG. 1. - Craneometric variables used in morphometric analysis: skull lenght (1), basilar condyle lenght (2), nasal condyle length (3), nasal length (4), nasal width (5), width between meatuses (6), width between cygomatic arches (7), width between mastoid apophyses (8), frontal width (9), rostral width (10), braincase width (11), preorbital foramen width (12), premolar condyle length (13), diastema length (14), auditory bulla length (15), auditory bulla width (16), incisive width (17), $\mathrm{P}^{4}$ length (18), upper molar series length (19), upper jaw width (20), height of skull (21), basal length (22), lower jaw length (23), lower jaw height (24).

pairs, follows Massarini et al. (1991). Sperm preparations were produced by squeezing a droplet of fluid from the epidydimus and the seminal vescicles onto a slide, and fixed in $10 \%$ formalin. Geographic location of the populations sampled are shown in Fig. 2, whereas the coordinates of localities and samples sizes are given in Table 2. Ctenomys t. talarum specimens included in this study were collected at the type locality (Magdalena, Buenos Aires Province). Studied specimens were deposited in the Museo de Ciencias Naturales "Lorenzo Scaglia" from Mar del Plata, Buenos Aires Province, Argentina.

\section{RESULTS}

Ctenomys specimens from Córdoba localities showed variable karyotypes with diploid numbers ranging from $2 \mathrm{n}=44$ to 50 (Table 2).

The $2 n=44$ karyotype has 19 pairs of biarmed chromosomes, the majority subtelocentric, except pair A15 which is submetacentric, and A16 and A17 which are metacentrics. Pair A15 presents secondary constrictions in the long arm. There are two pairs of small telocentrics, the $\mathrm{X}$ is a medium sized metacentric and the $\mathrm{Y}$ chromosome is a small subtelocentric (Fig. 3A). 


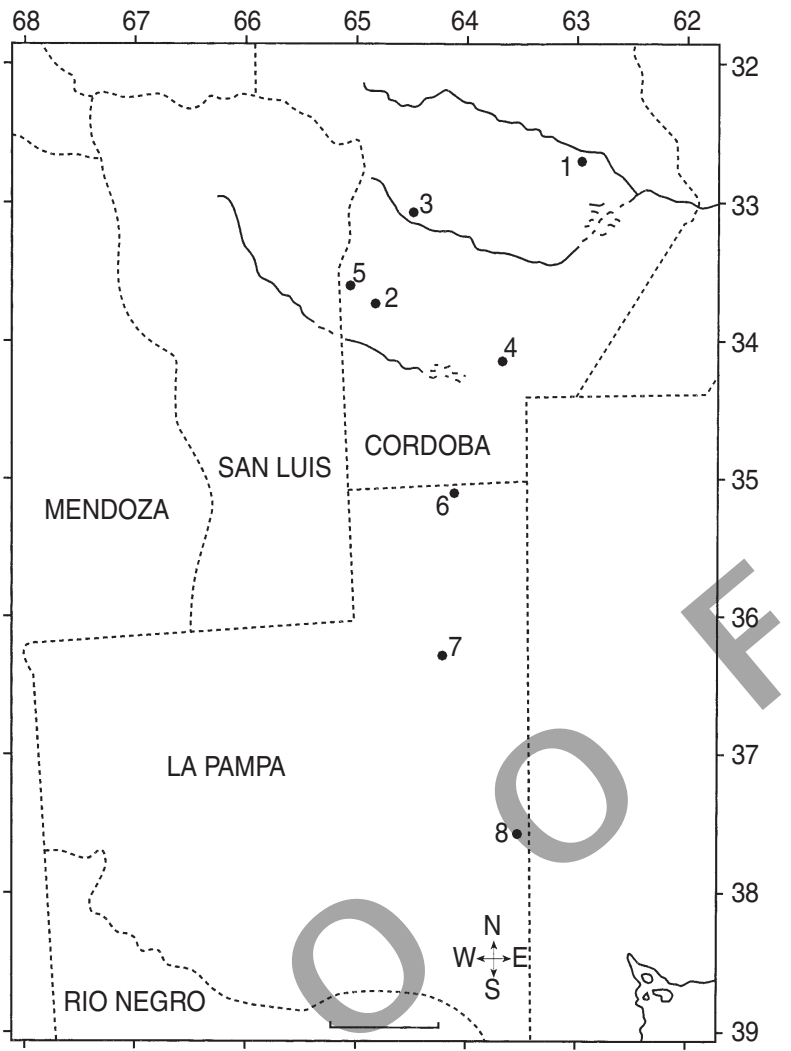

FIG. 2. - Geographic distribution of localities of collection included in this study. Puente Olmos (1), Santa Catalina (2), Holmberg (3), Vicuña Mackenna (4), Sampacho (5), Realicó (6), El Guanaco (7), and Guatraché (8). Bar represents 100 kms.

\begin{tabular}{|c|c|c|c|c|c|c|}
\hline Locality & males & females & Coordinates & Province & $2 n$ & FN \\
\hline Puente Olmos & 13 & 7 & $33^{\circ} 25^{\prime} \mathrm{S} 63^{\circ} 06^{\prime} \mathrm{W}$ & Córdoba & 50 & 86 \\
\hline Santa Catalina & 6 & 16 & $33^{\circ} 04^{\prime}$ ' S $64^{\circ} 32^{\prime} \mathrm{W}$ & Córdoba & 44 & 80 \\
\hline Holmberg & 1 & 1 & $33^{\circ} 13^{\prime}$ S $64^{\circ} 25^{\prime} \mathrm{W}$ & Córdoba & 44 & 80 \\
\hline Vicuña Mackenna & 0 & 6 & $33^{\circ} 54^{\prime} \mathrm{S} 64^{\circ} 23^{\prime} \mathrm{W}$ & Córdoba & $46-47-48$ & $80-82-84$ \\
\hline Sampacho & 5 & 4 & $33^{\circ} 23^{\prime}$ S $64^{\circ} 44^{\prime}$ W & Córdoba & 44 & 80 \\
\hline Realicó & 2 & 7 & $34^{\circ} 59^{\prime} \mathrm{S} 64^{\circ} 16^{\prime} \mathrm{W}$ & La Pampa & 46 & 80 \\
\hline El Guanaco & 1 & 6 & $36^{\circ} 19^{\prime} \mathrm{S} 64^{\circ} 17^{\prime} \mathrm{W}$ & La Pampa & 48 & 84 \\
\hline Guatraché & 0 & 1 & $37^{\circ} 41^{\prime} \mathrm{S} 63^{\circ} 31^{\prime} \mathrm{W}$ & La Pampa & 48 & 84 \\
\hline
\end{tabular}

Localities of collection of individuals, coordinates and provinces to which they belong, number of males and females of each sample, and diploid number (2n), and fundamental number (FN) found in each locality.

The $2 \mathrm{n}=46$ karyotype shows a similar chromosomal morphology as the $2 \mathrm{n}=44$, except that pair A19 is absent and there are two extra pairs of small telocentrics (B3 and B4) (Fig. 3B). The 2n
= 48 karyotype is similar to the $2 \mathrm{n}=46$ karyotype except that pair $\mathrm{A} 3$ is absent, and there are two extra pairs of chromosomes, one of which is a medium subtelocentric (A8) and the other is a 


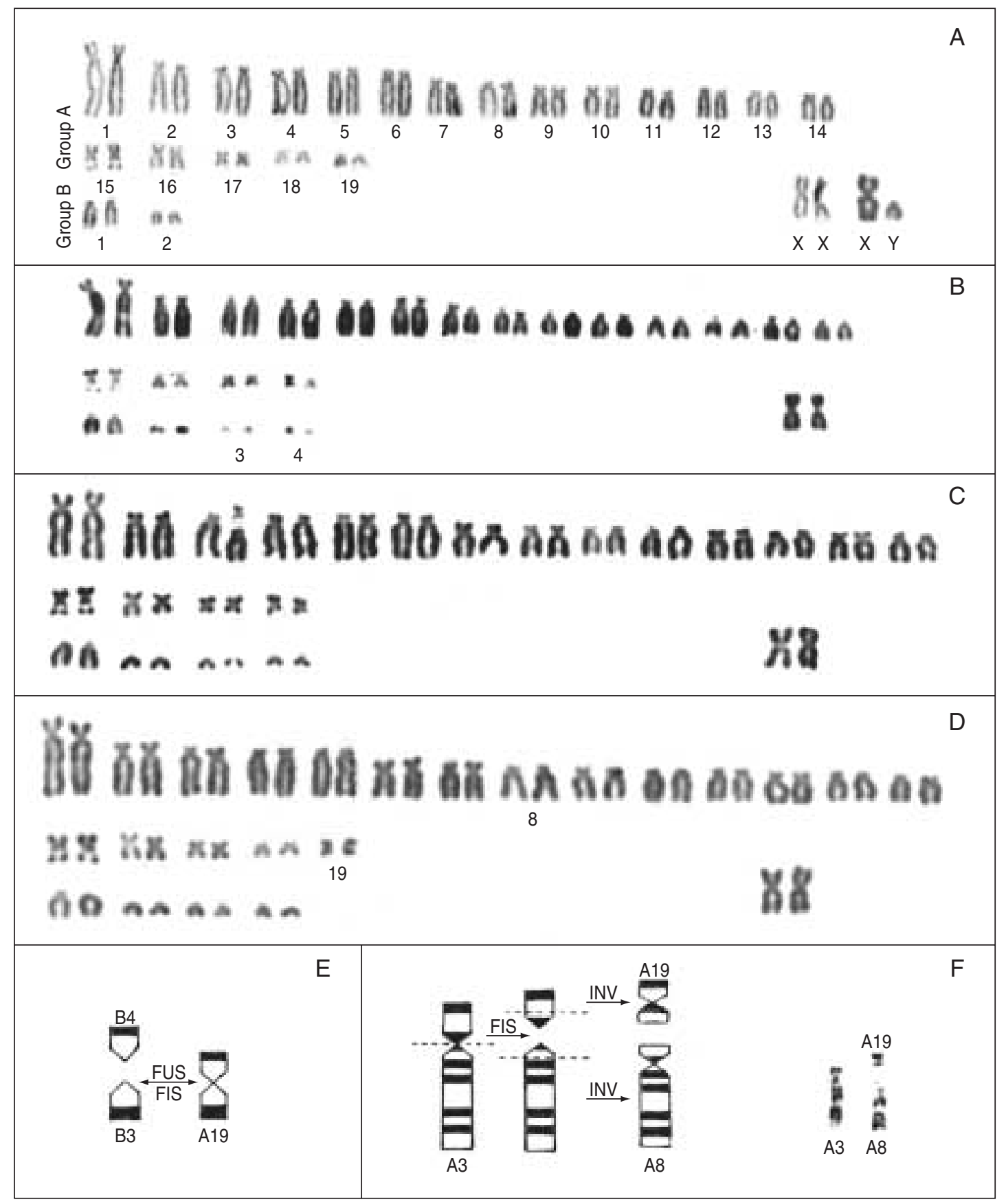

FIG. 3. - Nondifferentially stained karyotype of a female from Santa Catalina, and the sexual pair of a male, $2 n=44$ (A); karyotype of a female from Realicó, $2 n=46(B)$; heterokaryotype of a female from Vicuña Mackenna, $2 n=47$ (C); karyotype of a female from Vicuña Mackenna, $2 n=48$ (D); idiographic representation with G-bands of the chromosomal changes between the $2 n=44$ and the $2 n=46$ karyomorphs (E); idiographic representation with G-bands of the chromosomal rearrangements between the $2 n=46$ and the $2 \mathrm{n}=48$ karyomorphs $(\mathrm{F})$. Bar represents $10 \mu \mathrm{m}$. 


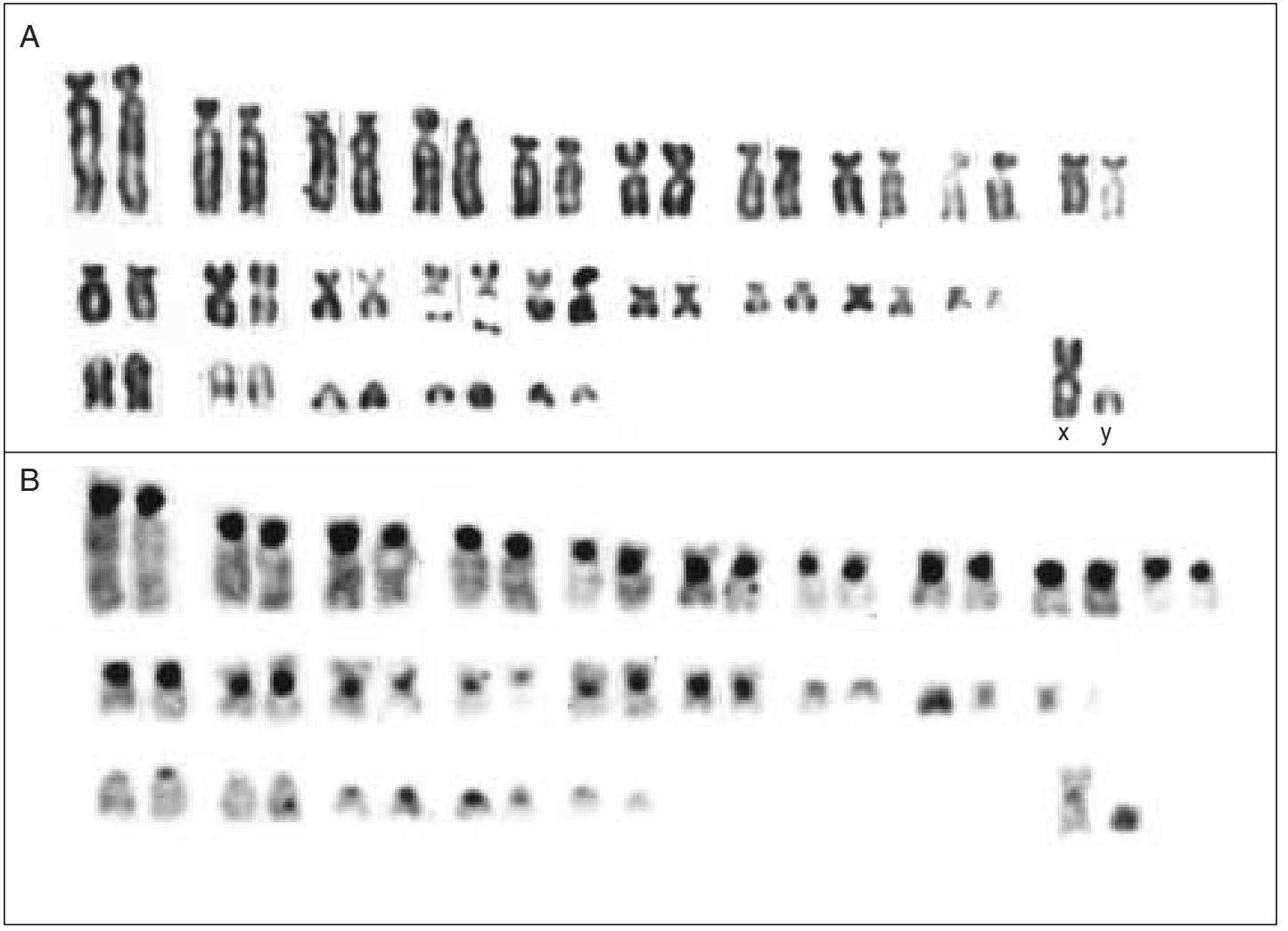

FIG. 4. - Nondifferentially stained karyotype of a male from Puente Olmos, with a diploid number of $2 n=50$ (A); sequential C-band karyotype of same cell (B). Bar represents $10 \mu \mathrm{m}$.

small metacentric (A19) (Fig. 3D). Individuals collected in Vicuña Mackenna were either homozygous for the $2 \mathrm{n}=46$ or $2 \mathrm{n}=48$ karyomorphs, or heterozygous with a karyotype of $2 \mathrm{n}$ $=47$. In the latter, there is an heteromorphic pair composed of a single A3 subtelocentric chromosome of the $2 n=46$ karyomorph, and one homologue of each of the two extra biarmed pairs of the $2 \mathrm{n}=48$ karyomorph (A8 and A19) (Fig. 3C, $3 \mathrm{~F})$.

The $2 \mathrm{n}=50$ karyotype found in Puente Olmos, has 19 pairs of biarmed chromosomes and 5 pairs of telocentric chromosomes. Eleven pairs of the biarmed chromosomes are subtelocentric, three pairs are submetacentric and five pairs are metacentric. Secondary constrictions are located in pair A14 (Fig. 4A). This karyotype differs from the $2 n=48$ karyotype in an extra pair of telocentrics, and in chromosome morphology of five pairs of biarmed chromosmes.

Sexual chromosomes in all studied karyotypes $(2 \mathrm{n}=44,46,47,48$ and 50$)$ show the same morphology, being the $\mathrm{X}$ a medium metacentric chromosome, and the $\mathrm{Y}$ a small subtelocentric.

C-banding showed a typical pattern of centromeric and pericentromeric heterochromatin distribution in biarmed chromosomes, and centromeric in telocentrics. The $\mathrm{X}$ chromosome shows centromeric heterochromatin, and the long arm of the $\mathrm{Y}$ is totally heterochromatic (Fig. 4B).

Comparisons of G-banded karyotypes showed that the differences between $2 n=44$ and $2 n=46$ karyomorphs are due to a single Robertsonian 


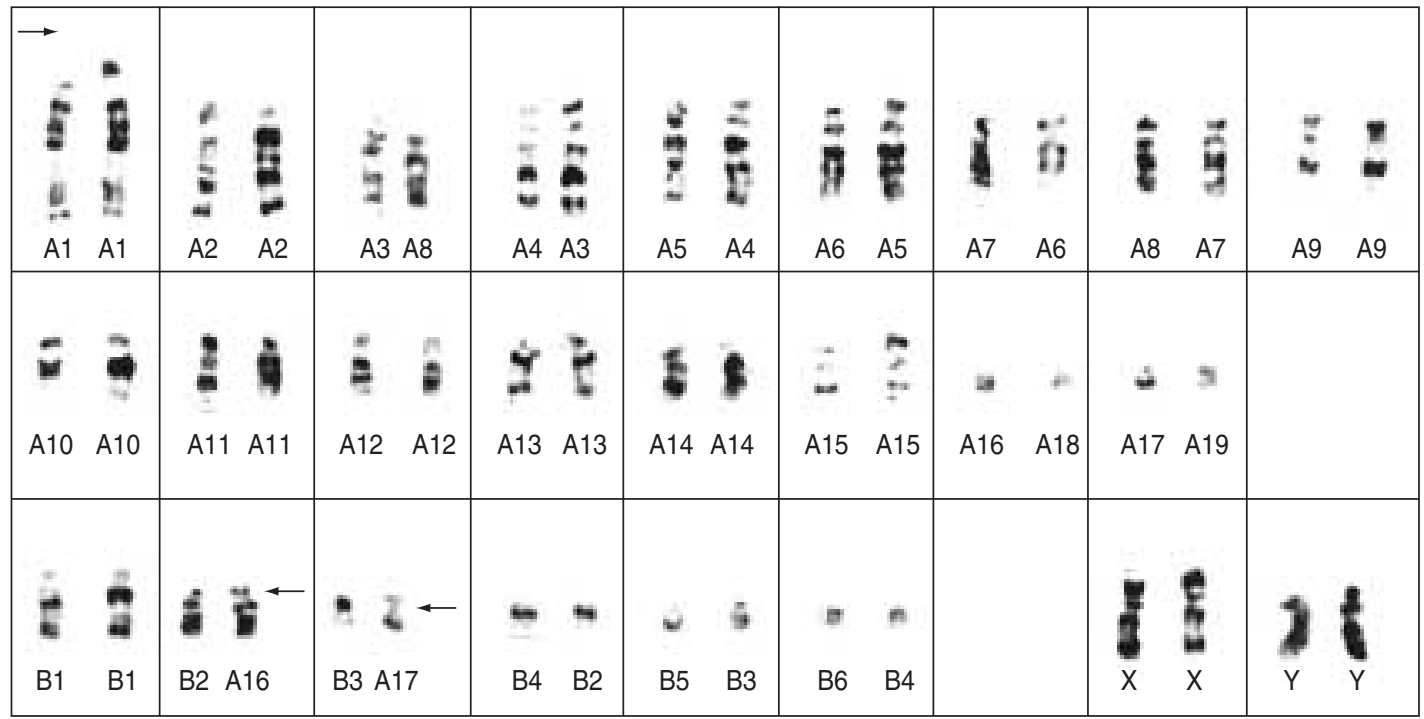

FIG. 5. - Arm to arm comparisons of G-banded chromosomes of a $2 n=48$ male from El Guanaco (right chromosome of each pair), and a $2 n=48$ Ctenomys $t$. talarum male from its type locality (left chromosome). Arrows show the chromosomal changes between these two karyomorphs. Bar represents $10 \mu \mathrm{m}$.

rearrangement involving pairs B3 and B4 of the All specimens analysed in this study, showed the $2 \mathrm{n}=46$ karyotype, and pair $\mathrm{A} 19$ of the $2 \mathrm{n}=44$ symmetric type of sperm morphology.

karyotype (Fig. 3E). However, a complex series The discriminant function analysis of morphoof rearrangements, that include a fission and two inversions, differentiate the $2 \mathrm{n}=46$ karyomorph from the $2 \mathrm{n}=48$ (Fig. 3F). The chromosomal pairs involved in this rearrangement are $\mathrm{A} 3$ of the $2 \mathrm{n}=46$ karyotype and pairs A8 and A19 of the $2 \mathrm{n}=48$ karyotype. Arm to arm comparisons between $2 n=48$ and $2 n=50$ karyotypes showed an $83 \%$ homology. Nevertheless, four pairs of chromosomes of the $2 \mathrm{n}=50$ karyotype, did not show any homology with the chromosomes of the $2 n=48$ karyotype, and neither did three pairs of the $2 n=48$ karyotype with the $2 n=50$ karyotype.

G-banding comparisons between the karyomorph of $2 \mathrm{n}=48$ from El Guanaco and the $2 \mathrm{n}=$ 48 karyotype of Ctenomys t. talarum from the type locality, shows $95 \%$ homology. Three inversions and two deletions affecting pairs $\mathrm{A} 1, \mathrm{~A} 3$, $\mathrm{B} 2$ and $\mathrm{B} 3$ of C. t. talarum and pairs A1, A8, A16 and $\mathrm{A} 17$ of the $2 \mathrm{n}=48$ karyotype from El Guanaco, can account for the observed differences (Fig. 5). metric data (Table 3A \& 3B) showed that for both sexes it is possible to distinguish clusters of populations that correspond to different species. The first discriminant function, which accounts for 51 and $59 \%$ of total variance in males and females respectively, shows the presence of two clusters. One of the clusters includes populations of C. t. talarum and C. pundti, with negative values; and the second cluster, species of the $C$. mendocinus group, with values greater or equal to 0 . In males, the second discriminant function (which explains $22 \%$ of total variance) separates, within the first group, populations of C. t. talarum, with negative values, from those of the $C$. pundti complex, with positive values. In females, $C$. t. talarum and $C$. pundti presented positive values and negative values, respectively, for the second discriminant function function (which accounts for $21 \%$ of total variance). In the mendocinus group the second function allows to distinguish in males, populations of $C$. azarae, with high positive values, from those of $C$. porteousi and 
3A.

TABLE 3. - Morphometric data.

\begin{tabular}{rllrrr}
\hline OTU No & Population & Species & Function 1 & Function 2 & Function 3 \\
\hline 1. & Necochea & C. australis & 9.7053 & 5.0685 & 1.6920 \\
2. & San Isidro & C. mendocinus & 2.6105 & -1.2180 & 4.1611 \\
3. & Bonifacio & C. porteousi & 1.4466 & -0.5644 & 1.8015 \\
4. & Magdalena & C. t. talarum & -5.2721 & 2.8381 & 0.6561 \\
5. & Santa Clara & C.t. talarum & -6.3524 & 1.4897 & 0.2659 \\
6. & Santa Catalina & C. pundti & -2.6156 & -2.6320 & -4.0353 \\
7. & Puente Olmos & C. pundti & -1.4203 & -3.4226 & -3.5179 \\
8. & Vicuña Mackenna & C. pundti & -2.0978 & -1.2531 & -3.7424 \\
9. & Realicó & C. pundti & -3.1352 & -2.2690 & -4.0646 \\
10. & El Guanaco & C. pundti & -3.2941 & -1.0408 & -2.9524 \\
11. & Santa Rosa & C. azarae & 3.2314 & -5.7145 & -0.0354 \\
12. & Anguil & C. azarae & 5.6099 & -3.9273 & -1.0431 \\
\hline & & & & \\
3B. & & & & & \\
\hline OTU No & Population & Species & Function 1 & Function 2 & Function 3 \\
\hline 1. & Claromecó & C. australis & 4.9198 & -4.1121 & 0.2967 \\
2. & Monte Hermoso & C. australis & 4.4699 & -1.0612 & 0.2081 \\
3. & Necochea & C. australis & 4.4434 & -1.0385 & -1.9385 \\
4. & San Isidro & C. mendocinus & -0.0206 & 0.4028 & -3.6319 \\
5. & Bonifacio & C. porteousi & 1.1253 & 1.2356 & -2.0884 \\
6. & Magdalena & C. t. talarum & -2.4819 & -2.5446 & 0.3217 \\
7. & Santa Clara & C. t. talarum & -2.8949 & -1.5727 & -0.1595 \\
8. & Santa Catalina & C. pundti & -3.7032 & 1.7439 & 1.4665 \\
9. & Puente Olmos & C. pundti & -3.1502 & 2.4916 & 2.0713 \\
10. & Santa Rosa & C. azarae & 1.3934 & 4.0621 & 0.4882 \\
\hline
\end{tabular}

Values correspond to the first three functions (Axis 1, 2, and 3) of Discriminant Function Analysis, based on the morphometric data of Females (3A) and: Males (3B).

C. mendocinus, with low positive values and C. australis with negative values. In females, the second function allows to distinguish within the mendocinus group, C. azarae populations with high negative values from $C$. porteousi and $C$. mendocinus with low negative values, and from C. australis which had positive values. The third discriminant function, which accounts for $11 \%$ of total variance in both sexes, allows to differentiate in C. mendocinus from C. porteousi (Fig. 6A $\& 6 B)$. It is worth noting that the percentages of well classified specimens was $100 \%$ in males and, on average, $96.5 \%$ in females. Misclassified females correspond to cases of individuals sampled in different populations of the same subspecies (3 out of 21 specimens of C. t. talarum), in different localities of the same species (1 out five specimens of $C$. pundti), and in individuals that belong to different species of the mendocinus group ( 2 out of 36 specimens of $C$. porteusi and $C$. mendocinus).

\section{DISCUSSION}

The analysis of chromosomal homologies by means of G-banded karyotypes show that the $2 \mathrm{n}$ $=46$ (Realicó), $2 \mathrm{n}=48$ (El Guanaco and Guatraché) populations, and the polymorphic population of Vicuña Mackenna $(2 \mathrm{n}=46,47$, 48) are closely related. The $2 \mathrm{n}=44$ populations from Santa Catalina, Holmberg and Sampacho are karyologically undistinguishable, and differ from the rest of the forms by a single Robertsonian change. The rearrangements that explain the differentiation between the $2 n=46$ 
A

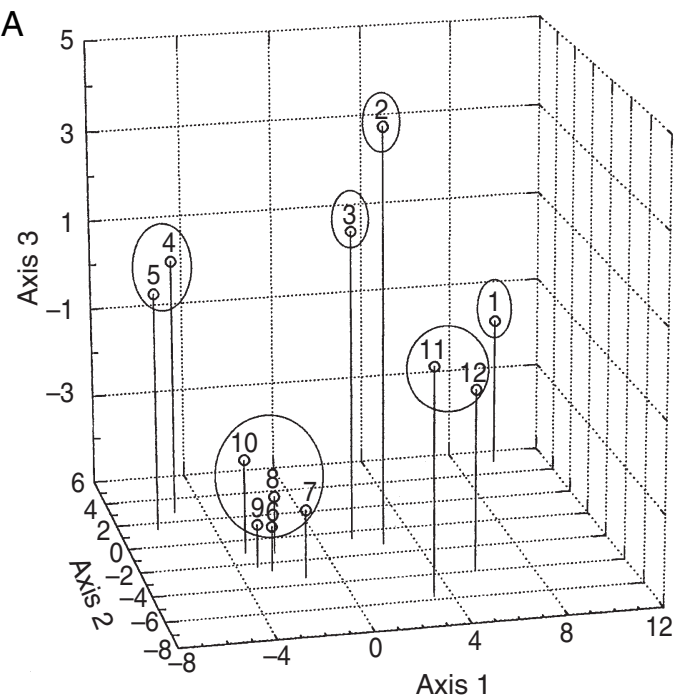

B

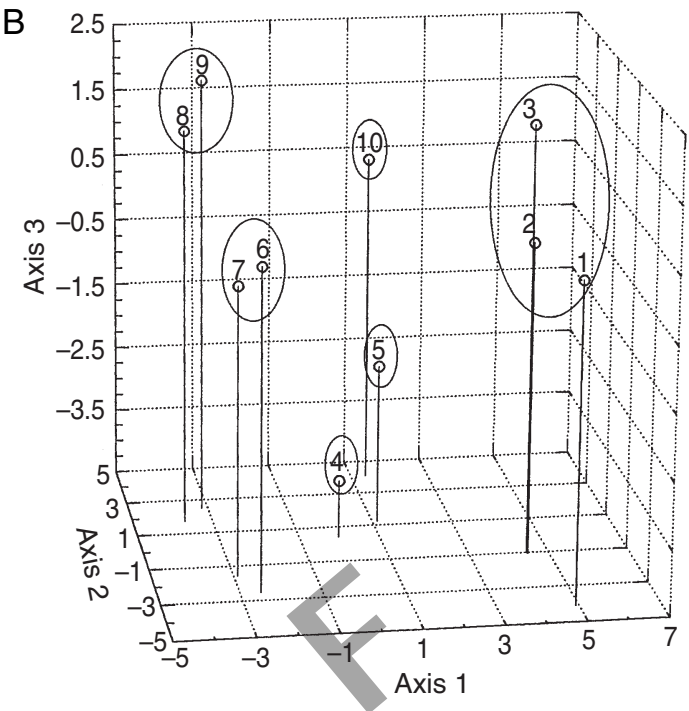

FIG. 6. - Graphical representation of the first three functions of Discriminant Canonical Analysis based on morphometric data for females (A) and males (B). Only centroids of each a priori defined group are plotted. Circles assemble populations belonging to the same species. In females (A) population 1 belongs to C. australis, 2 to C. mendocinus, 3 to C. porteusi, 4-5 to C. t. talarum, 6-10 to C. pundti and 11-12 to C. azarae. In males (B) populations 1-3 belong to C. australis, 4 to C. mendocinus, 5 to $C$. porteusi, 6 to C. talarum, 8-9 to C. pundti and 10 to C. azarae.

and $2 \mathrm{n}=48$ karyotypes, involve a complex set of the homogeneity within lineages of Ctenomys. On mutation events that suggests a significant dis- one side the $C$. mendocinus group shares the tinction between these two forms. However, the asymmetric sperm type, and a high degree of existence of the $2 n=47$ heterokaryotype in Vicuña Mackenna points out that this incipient chromosomal differentiation does not involve reproductive isolation.

The $2 n=50$ karyotype from Puente Olmos is the more divergent. With the data presented so far, it was not possible to establish the nature of the chromosomal rearrangements involved in karyotypic divergence, but it is expected that high resolution G-banding would provide an answer to this question.

The close phylogenetic relationships between $C$. talarum and the C.pundti complex, is well supported by two different kind of evidence: the great chromosomal homology and the sharing of the same type of sperm. Although, they undoubtedly belong to the same evolutionary lineage, morphological and cytogenetic differentiation suggest that these are recently diverged species. Cytogenetic and sperm morphology evidence along with the morphometric analysis support chromosomal uniformity, but these taxa are morphologically differentiated from each other. On the other side, the populations of the C.pundti complex and $C$. talarum, also share the same symmetric sperm morphology and a significant degree of chromosomal homology. Morphometric analysis allows to distinguish C. t. talarum from the C. pundti complex, but populations of the latter, though variable in chromosome number, cannot be discriminated by means of morphometric criteria. In this sense, it is noteworthy that the level of morphological differentiation that exists between populations of the $C$. pundti complex, is comparable to differentiation among C. azarae populations.

Based solely on morphology, Justo (1992) described a new subspecies of C. talarum (C. t. occidentalis) from La Pampa and included samples from El Guanaco. However, our present study shows that the latter is better referred to as belonging to the $C$. pundti complex rather than 
to C. t. talarum, on grounds of cytogenetic and morphometric criteria. Similarly, we propose that rest of the populations studied by Justo should be assigned to the pundti complex, which conform a closely related but distinguishable unit from C. talarum.

Despite the growing amount of information available for these forms, there exists a nomenclatorial problem regarding C. pundti. Nowadays, in the type locality of this species (Alejo Ledesma), there are no tuco-tucos, due to the intense ecosystem modification brought upon by agriculture. The nearest population of tuco-tucos is in Puente Olmos, which is $50 \mathrm{~km} \mathrm{~W}$ of Alejo Ledesma (Reig et al. 1992). Therefore, we propose to use the name $C$. pundti for the $2 \mathrm{n}=50$ population from Puente Olmos. Additionally, this one and the rest of the populations $(2 \mathrm{n}=44,46,47,48)$ should be included in the $C$. pundti complex until more information is available to further solve the taxonomy and systemtics of these comlex forms from Central Argentina.

\section{Acknowledgments}

This paper is dedicated to the memory of Dr. O.A. Reig without whom this work would not have been feasible. This research has been partially funded by CONICET (PICT AgenciaCONICET 211) and UBACYT (grant No EX020). SIT wishes to give special recognition to M. P. Torres and E. Massoia for sharing their knowledge of the genus Ctenomys.

\section{REFERENCES}

Anderson S., Yates T. L. \& CoOK J. 1987. — Notes on Bolivian mammals. 4: The genus Ctenomys (Rodentia: Ctenomyidae) in the eastern lowlands. American Museum Novitates 2891: 1-20.

BAKer R. J., Chesser R. K., KoOP B. F. \& hOYT R. A. 1983. - Adaptive nature of chromosomal rearrangement: differential fitness in pocket gophers. Genetica 61: 161-164.

Contreras J. R. \& Reig O. A. 1965. - Datos sobre la distribución del género Ctenomys (Rodentia: Octodontidae) en la zona costera de la Provincia de Buenos Aires comprendida entre Necochea y Bahía Blanca. Physis 25: 169-186.
Cook J. A., Anderson S. \& YATes T. L. 1990. Notes on Bolivian mammals. 6. The genus Ctenomys (Rodentia, Ctenomyidae) in the highlands. American Museum Novitates 2980: 1-27.

D’Elía G., Lessa E. P. \& CoOK J. A. 1999. Molecular phylogeny of Tuco-tucos, genus Ctenomys (Rodentia: Octodontidae): evaluation of the mendocinus species group and the evolution of asymmetric sperm. Journal of Mammalian Evolution 6 (1): 19-38.

FrEITAS T. R. O. 1994. - Geographical variation of heterochromatin in Ctenomys flamarioni (Rodentia: Octodontidae) and its cytogenetics relationships with other species of the genus. Cytogenet. Cell Genetics 67: 193-98.

Freitas T. R. O. 1995. - Geographical distribution of sperm forms in the genus Ctenomys (Rodentia: Octodontidae). Rev. Brasil. Genet. 18 (1): 43-46.

FreitAs T. R. O. 1997. Chromosome polymorphism in Ctenomys minutus (Rodentia: Octodontidae). Brazilian Journal of Genetics 20 (1): 1-7.

Gallardo M. H. 1991. - Karyotype evolution in Ctenomys (Rodentia: Ctenomyidae). Journal of Mammalogy 72 (1): 11-21.

Giménez M. D., Bidau C. J., Argüelles C. F. \& Contreras J. R. 1999. - Chromosomal characterization and relationship between two new species of Ctenomys (Rodentia, Ctenomyidae) from northern Córdoba province, Argentina. Z. Säugertierk. 64: 91-106.

Hsu T. C. 1974. - Procedures for inducing C-bands and G-bands in mammalian chromosomes. Mamm.Chromosome Newsl. 15: 88-96.

JusTO E. R. 1992. - Ctenomys talarum occidentalis: una nueva subespecie de tuco-tuco (Rodentia: Octodontidae) en La Pampa, Argentina. Neotropica 38(99): 35-40.

LEE M. R. \& ELder F. 1980. - Yeast stimulation of bone marrow mitoses for cytogenetic investigation. Cytogenet. Cell Genet 26: 36-40.

Levan A., Fredga K. \& Sandber G. A. 1964. Nomenclature for centromeric position in chromosomes. Hereditas 52: 201-220.

MASSARINI A. I. 1992. - Evolución cromosómica de las especies de Ctenomys de la Región Pampeana y de Cuyo. PhD. Thesis, Universidad de Buenos Aires, Argentina: $147 \mathrm{p}$.

Massarini A. I., Dyzenchauz F. J. \& Tiranti S. I. 1998. - Geographic variation of chromosomal polymorphism in nine populations of Ctenomys azarae, tuco-tucos of the Ctenomys mendocinus group (Rodentia: Octodontidae). Hereditas 128: 207-211.

Massarini A. I., Barros M. A., Ortells M. O. \& REIG O. A. 1991. - Chromosomal polymorphisms and small karyotypic differentiation in a group of Ctenomys species from central Argentina (Rodentia: Octodontidae). Journal of Mammalogy 72 (1): 194-198. 
NeHring A. 1900. - Uber Ctenomys pundti n. sp. und Ct. minutus Nhrg. Zoologischer Anzeiger 23: 420-425.

NEvo E. 1991. - Evolutionary theory and processes of active speciation and adaptive radiation in subterranean mole rats, Spalax ehrenbergi superspecies in Israel, in Hecht M. K., Wallace B. \& MacIntyre R. J. (Eds), Evolutionary Biology Vol. 25. Plenum Press, New York: 1-125.

OrTELLs M. O. 1990. - Biología Evolutiva del género Ctenomys. PhD Thesis. Universidad de Buenos Aires, Argentina: $\bullet \bullet p$.

Ortells M. O. 1995. - Phylogenetic analysis of G-banded karyotypes among the South American subterranean rodents of the genus Ctenomys (Caviomorpha, Octodontidae), with special reference to the chromosomal evolution and speciation, Biological Journal of the Linnean Society 54: 43-70.

Ortells M. O. \& Barrantes G. 1994. - A study of genetic distances and variability in several species of the genus Ctenomys (Rodentia, Octodontidae) with special reference to a probable causal role of chromosomes in speciation. Biological Journal of the Linnean Society 53 (2): 189-208.

Ortells M. O., Contreras J. R. \& Reig O. A. 1990. - New Ctenomys karyotypes (Rodentia, Octodontidae) from north-eastern Argentina and from Paraguay confirm the extreme chromosomal multiformity of the genus. Genetica 82: 189-201. ReIG O. A., BuSCH C., ORTElls M. O. \& CONTRERAS
J. R. 1990. - An overview of evolution, systematics, population biology, cytogenetics, molecular biology, and speciation in Ctenomys, in NEVO E. \& REIG O. (Eds), Evolution of subterranean mammals at the organismal and molecular levels: Proceedings of the Fifth Theriological Congress, Rome, Italy. A Liss A. R. New York: 71-96.

Reig O. A. \& Kiblisky P. 1969. - Chromosome multiformity in the genus Ctenomys (Rodentia: Octodontidae). Chromosoma 28: 211-244.

ReIG O. A. 1989. - Karyotypic repatterning as one triggering factor in cases of explosive speciation, in Fontdevila A. (Ed.), Evolutionary Biology of Transient Unstable Populations. Springer-Verlag, Berlin, Heidelberg: $\bullet \bullet \bullet \bullet \bullet \bullet$.

Reig O. A., Ortells M. O., Massarini A. I., Barros M. A., Tiranti S. I. \& Dyzenchauz F. J. 1992. New karyotypes and C-banding patterns of the subterranean rodents of the genus Ctenomys (Caviomorpha: Octodontidae) from Argentina. Mammalia 56 (4): 603-623.

SEABRIGHT M. 1971. - A rapid banding technique for human chromosomes. Lancet 2: 971-972.

Thomas O. 1903. - New species of Oxymycterus, Trichomys and Ctenomys from South America. Annals and Magazine of Natural History 11: 226-229.

VIDAL RIOJA L. 1985. - Chromosome polymorphisms in Ctenomys talarum (Rodentia: Octodontidae). Caryologia 38: 169-178.

Vitullo A. D. \& CoOK J. A. 1991. - The role of sperm morphology in the evolution of tuco-tucos Ctenomys (Rodentia: Ctenomyidae): Confirmation of results from Bolivian species. Z. Saugetierkd. 56: 359-364.

Vitullo A. E., Roldán R. S. \& Merani M. S. 1988. - On the morphology of the spermatozoa of tucotucos, Ctenomys (Rodentia: Ctenomydae): New data and its implication for the evolution of the genus. Journal of Zoology London 215: 675-683. 